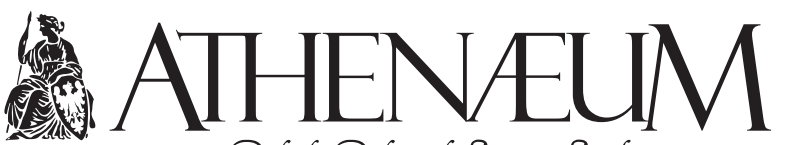

Polish Political Science Studies

Polskie Studia Politologiczne

vol. 59/2018, pp. 178-204

DOI: 10.15804/athena.2018.59.12

www.athenaeum.umk.pl

ISSN 1505-2192

(c) $(1) \odot$

\title{
THE RIGHT OF INDIGENOUS PEOPLES TO SELF-DETERMINATION: INTERNATIONAL LAW PERSPECTIVE
}

\author{
PRAWO LUDÓW TUBYLCZYCH DO SAMOSTANOWIENIA. \\ PERSPEKTYWA PRAWNOMIĘDZYNARODOWA
}

\author{
Agnieszka Szpak*
}

\begin{abstract}
The author offers an international law perspective on a specific issue of self-determination of indigenous peoples. The article begins with the definition of indigenous peoples, then proceeds to self-determination in general. The last section examines the forms of indigenous selfdetermination and its meaning for indigenous peoples. Indigenous peoples have a right to self-determination which allows them for control over their destiny, their livelihoods, their culture and customs. It may be realized, most of all, in the form of autonomy or self-governance. As such, self-determination allows indigenous peoples to participate in decision making in matters that affect their rights.
\end{abstract}

Keywords: indigenous peoples, self-determination, autonomy, self-governance, international law
Autorka analizuje prawo ludów tubylczych do samostanowienia $\mathrm{z}$ perspektywy prawa międzynarodowego. Artykuł zaczyna się od wyjaśnienia definicji ludów tubylczych jako podmiotu prawa do samostanowienia. W kolejnej części analizie poddano prawo do samostanowienia w ogólności, po czym wskazano formy samostanowienia ludów tubylczych i jego znaczenie dla tych ludów. Ludy tubylcze mają prawo do samostanowienia, które pozwala im kontrolować ich przeznaczenie, sposób życia, kulturę i zwyczaje. Można to osiągnąć przede wszystkim w formie autonomii lub samorządności. Jako takie samostanowienie pozwala ludom tubylczym uczestniczyć w podejmowaniu decyzji w sprawach mających wpływ na ich prawa.

Słowa kluczowe: ludy tubylcze, samostanowienie, autonomia, samorządność, prawo międzynarodowe

* Nicolaus Copernicus University in Toruń, Faculty of Political Sciences and International Studies. ORCID: https://orcid.org/0000-0001-7601-1230. 


\section{INTRODUCTION}

Globally indigenous peoples constitute about 370 million individuals which makes about 5 percent of the world population. They live in more than 70 States (UN Resource Kit, 2008, p. 10; Symonides, 2007, p. 235). For many years, indigenous peoples (for example the Sami in the Arctic, Aboriginal peoples in Australia, First Nations in North America, Inuit in Greenland), their needs, rights, cultures and identity have been interfered with but indigenous peoples have resisted, persisted and persevered. Their situation has been slowly changing in practice while on paper international instruments both of 'hard law' and 'soft law' contain provisions ensuring respect for the rights of indigenous people such as, inter alia, right to self-determination, to respect for their traditions and customs, cultures and languages, to participate in decision-making on matters that would affect their rights, land rights, to the improvement of their social and economic position, or to maintain and develop their traditional knowledge.

In 1994, the UN General Assembly declared years 1995-2004 the International Decade of the World's Indigenous Peoples (UN GA res. 48/163, 1993). The second decade (2005-2015) was the continuation of the first one (UN Ga res. 59/174, 2004). The first decade was supposed to be crowned by the issuance of the UN declaration on indigenous peoples but this happened only in the middle of the second decade when in 2007 the UN Declaration on the Rights of Indigenous Peoples was adopted. Many of the above listed rights are guaranteed in the non-binding UN Declaration on the Rights of Indigenous Peoples (hereinafter: UN Declaration, http://research.un.org/en/docs/ga/quick/regular/61) and legally binding ILO Convention 169 on Indigenous and Tribal Peoples in Independent Countries. The ILO Convention aims to protect the rights of indigenous peoples, their way of life and their culture. Its adoption was at that time (in 1989) an improvement compared to the previous Convention 107 of 1957 on the Protection and Integration of Indigenous and Other Tribal and Semi-Tribal Populations in Independent Countries which aimed at assimilation of indigenous peoples. One may conclude that there are quite progressive legal provisions protecting the indigenous peoples, but unfortunately, law in books does not always transform into law in action.

In this paper, the author will offer an international law perspective on a specific issue of self-determination of indigenous peoples. The author will examine legal instruments that refer to self-determination of indigenous peoples, forms that self-determination of indigenous peoples may take and its meaning for 
those peoples. The purpose of the article is to answer the research question whether indigenous peoples have the right to the same self-determination as other peoples or maybe there are some differences in this regard. Related questions are: What are the expressions of the indigenous self-determination or self-governance? The research method used is that of legal analysis of the international law instruments pertaining to indigenous peoples as well as contents analysis of the relevant literature. The structure of the article is as follows: section 2 will concentrate on the definition of indigenous peoples which should be a starting point when analyzing a legal right - one must know the subject of such a right. Section 3 will focus on self-determination in general in order to outline its scope and prepare the basis for a more concrete and detailed issue of the forms of indigenous self-determination which will be examined in section 4. In this section, the author will also examine the legal regulations pertaining to self-determination of indigenous peoples and autonomy. Finally, section 5 will contain concluding remarks and answers to the research questions.

\section{DEFINITION OF INDIGENOUS PEOPLES IN INTERNATIONAL LAW}

First, it is necessary to define the term 'indigenous peoples' as they are the subject of the right to self-determination. In order to determine the personal scope of this right, one has to know who is entitled to it. The term 'indigenous peoples' has been used to denote distinct peoples who have lived from time immemorial on a certain territory (who are so called 'first people') and who have been pursuing their own concept of development and attempting to maintain their identity, languages, traditional customs, beliefs and values, their lifestyles and control over their lands and natural resources (UN Resource Kit, 2008, p. 7). This paper adopts the definition of indigenous peoples of José Martínez-Cobo:"Indigenous communities, peoples and nations are those which, having a historical continuity with pre-invasion and pre-colonial societies that developed on their territories, consider themselves distinct from other sectors of the societies now prevailing on those territories, or parts of them. They form at present non-dominant sectors of society and are determined to preserve, develop and transmit to future generations their ancestral territories, and their ethnic identity, as the basis of their continued existence as peoples, in accordance with their own cultural patterns, social institutions and legal systems" (1986/87). The only normative definition of indigenous peoples was formulated in the ILO Convention 169 (see: Art. 1). As 
far as indigenous peoples are concerned, it contains a more relaxed requirement for historical continuity, since it does not mention the period before the invasion or colonization.

It is worth pointing to the factors necessary to the concept of indigenous peoples such as:

- "Priority in time, with respect to the occupation and use of a specific territory;

- The voluntary perpetuation of cultural distinctiveness, which may include the aspects of language, social organization, religion and spiritual values, modes of production, laws and institutions;

- Self-identification, as well as recognition by other groups, or by State authorities, as a distinct collectivity; and

- An experience of subjugation, marginalization, dispossession, exclusion or discrimination, whether or not these conditions persist" (UN Resource Kit, 2008, p. 8; Magnarella, 2001-2002, p. 426; Meijknecht, 2002-2003, pp. 316-318).

Self-identification is the basic criterion for determining the indigenousness (ILO Convention 169, Art. 1.2; American Declaration on the Rights of Indigenous Peoples (2016), Art. 1.2; Working Paper on the Concept of Indigenous People, 1996, p. 22).

Definition of indigenous peoples is controversial, especially in Asia and Africa. In Asia many countries do not recognize indigenous peoples (e.g., India, China, Bangladesh, and Myanmar), and in the rest of Asia their situation is very diverse (Kingsbury, 2008, pp. 121-122). Refusal to recognize indigenous peoples is based on the claim that all citizens are equally indigenous but this approach is an expression of the assimilationist attitudes of States. This in turn is a manifestation of ongoing discrimination against indigenous peoples. The legal recognition of these peoples does not necessarily have to guarantee the observance of their collective and individual rights as long as the law is not actually implemented (Indigenous Peoples and ASEAN Integration, 2015, p. 44).

Hanna Schreiber classifies arguments against the recognition of indigenous peoples raised by Asian and African states as definitional, practical and political arguments. The first concerns a controversial reference to the times of colonialism and invasion (the doctrine of 'salt water'). According to this argument, imposing on Asian or African States of the concept of indigenous peoples is a new form of colonialism. According to practical arguments, it is very difficult or even impossible to prove who was first in the territory at question. Lastly, political arguments 
are based on fears of States that recognizing certain indigenous peoples' rights will lead to escalation of demands - other groups will also make similar claims (Schreiber, 2009, p. 156; Oguamanam, 2004, p. 360, 369-371).

The controversy surrounding the definition of indigenous peoples in its application to Asia was also highlighted by the UN Special Rapporteur on the Rights of Indigenous Peoples, James Anaya. In his report of July 31, 2013, he stated that he was aware that the vast majority of the population in Asia could be considered indigenous. On the other hand, the Special Rapporteur noted that there were special groups in Asia that differed from the general population which were within the framework of indigenous peoples as that concept was construed under the auspices of the UN. These groups are today among the most discriminated, socially and economically marginalized and politically subordinated parts of the societies of Asian countries in which they live. Regardless of the controversy surrounding the definition of indigenous peoples, political actors in Asia (e.g., ASEAN) agree that there is a need to solve the problems of these groups and to recognize and implement their human rights and their collective rights analogously to the rights of indigenous peoples (Report of the Special Rapporteur..., 2013, p. 5, 6). In addition, according to the Special Rapporteur, the UN Declaration on the Rights of Indigenous Peoples applies to indigenous peoples of Asia, including tribal peoples, which are not recognized by the governments of Asian countries (Report of the Special Rapporteur..., 2013, p. 6). In his monograph on indigenous peoples, James Anaya defines these peoples as "living descendants of preinvasion inhabitants of lands now dominated by others. Indigenous peoples, nations, or communities are culturally distinctive groups that find themselves engulfed by settler societies born of the forces of empire and conquest" (1996, p. 3; Report of the African Commission's Working Group of Experts on Indigenous Populations/Communities Submitted in Accordance with the "Resolution on the Rights of Indigenous Populations/Communities in Africa", 2005, pp. 89-90; Operational Policy 4.10, 2005, paras. 3, 4; Policy on Indigenous Peoples, 1998, p. 3; MacKay, 2005, p. 72).

Among the characteristic features of indigenous peoples are those that are common and at the same time do not limit the application of the definition only to the Euro-American-Australian context:

1. Indigenous peoples identify themselves as indigenous and are, as such, accepted by members of that group (self-identification at individual and group level);

2. They have strong connection to their lands and natural resources; 
3. They maintain, at least in part, separate social, economic and political systems;

4. They have preserved, at least in part, distinct languages, culture, beliefs and systems of knowledge;

5. They are determined to preserve and develop their identity and distinct social, economic, cultural and political institutions.

The requirements of historical continuity and temporal priority are considered unnecessary, but rather as additional factors for identifying/confirming the indigenous nature of a given group (rather identifying than defining). Another factor to consider for the identification of indigenous peoples may be, inter alia, the recognition of the indigenous peoples in national laws (in the constitution or other statutes) (UN Resource Kit, 2008, p. 9). Most of all, however, the basic criterion for the identification of indigenous peoples is self-identification, hence the voice of indigenous peoples is crucial, taking into account the specificity and concrete circumstances of each group (UN Resource Kit, 2008, p. 9). Even on the basis of this brief sketch, it is clear that much depends on the understanding of the concept of indigenous peoples, and this clearly impacts the scope of the right to self-determination, but it should be borne in mind that ILO Convention 169 applies also to tribal peoples.

\section{THE RIGHT TO SELF-DETERMINATION IN GENERAL}

The principle of self-determination is one of the fundamental principles of international law, which has its roots in the principle of sovereignty. The common Art. 1 of the International Covenant on Civil and Political Rights and International Covenant on Economic, Social and Cultural Rights of 1966 states that "[a]ll peoples have the right of self-determination. By virtue of that right they freely determine their political status and freely pursue their economic, social and cultural development". The principle of sovereignty implicates an obligation on the all contracting parties to respect the right of every State to freely determine its own political system and social, economic and cultural development. Accordingly, force must not be used in order to deprive any State of this right or to impose certain system by the outside actor (Tyranowski, 1997, p. 402, 405; Cassese, 2005, p. 63). Principle of self-determination is also mentioned in Art. 1(2) of the UN Charter. This right is accorded to nations and peoples. 
Self-determination has two aspects: internal and external. The former means the right of a nation/people to realize its rights, interests, aspirations and sovereignty within the existing State, whereas the latter refers to the right to create a separate State (secession). Internal aspect of self-determination does not raise controversies, but the external one is very controversial and - as a rule - does not engage peoples without the consent of the existing State (Kałduński, 2010, p.444). Declaration on Principles of International Law Concerning Friendly Relations and Co-operation Among States in Accordance with the Charter of the United Nations of 1970 provides three forms of self-determination: establishment of a sovereign and independent State, free association with an independent State and any other political status freely determined by a people (http://www.un-documents.net/ a25r2625.htm).

The right to self-determination and secession are not identical, which means that only exceptionally self-determination is realized in the form of secession (Białocerkiewicz, 2007, p. 154). As already mentioned, the principle of selfdetermination is a fundamental principle of international law which should be considered in the context of the whole body of international law, i.e., most of all in the context of all the principles of international law enumerated in the $U N$ Charter such as prohibition of the use of force, territorial integrity or respect for human rights (Kałduński, 2010,p.449). The principle of territorial integrity is of special importance as it stands in clear opposition to self-determination in the form of secession. Secession means separation of the part of the State territory in order to create a new State (Crawford, 1979, pp. 247-270). It may also take the form of separation of the part of the territory to join another State. International law does not prohibit secession nor does it allow for a right to secession. As J. Vidmar (2014) claims, "international law is actually neutral on the question of unilateral secession. This means that unilateral secession is neither prohibited nor an entitlement". J. Crawford, who represent the majority view, states that international law allows for secession only with the consent of the existing State (Crawford, 2007). In general, "State practice is very reluctant to acknowledge a right to secession, since States fear that their own territorial integrity might be endangered by an empowerment of secessionist groups" (Marxsen, 2014), especially those States whose territorial integrity may be threatened or breached by the secessionist movements (inter alia Spain, Russia, China - Kownacki, 2010, pp. 100-110). In this context, one may notice that UN General Assembly resolution 1514 (XIV) of 1960 - Declaration on the Granting of Independence to Colonial Countries and Peoples - states that "[a]ny attempt aimed at the partial 
or total disruption of the national unity and the territorial integrity of a country is incompatible with the purposes and principles of the Charter of the United Nations" (para. 6). A similar provision may be found in resolution 2625 (XXV) of 1970 (Declaration on Principles of International Law Concerning Friendly Relations and Co-operation Among States in Accordance with the Charter of the United Nations). Those provisions clearly indicate that self-determination should be realized first of all in its internal aspect, for example, in the form of autonomy (within the existing State). For that reason some scholars claim that in practice principle of self-determination is subordinated to the principle of territorial integrity (Czapliński \& Wyrozumska, 2004, p. 142), hence the preference for internal aspect of self-determination is visible. On the other hand, as L. Antonowicz (2011, p. 48) notices, international law protects territorial integrity of States against any outside attacks but it does not envisage the protection against the disintegration from the inside because, as the result of the massive inside separatist movements secession may occur and it is not expressly prohibited by international law.

Generally, in practice self-determination may be realized in its internal form (autonomy). However, some scholars are of the opinion that there is exception to the requirement of consent, namely that of remedial secession (Cassese, 2005, p. 91, 68; Separate Opinion of Judge Cançado Trindade, para. 176; Antonowicz, 2012, p. 81; Barcik \& Srogosz, 2007, p. 41). This is still the minority view. Possibility of remedial secession has been endorsed by the Supreme Court of Canada in the case of Reference re Secession of Quebec (paras. 132-133,138). It will be legal when the population (peoples) is under the occupation, foreign domination, is exploited or their human rights are blatantly violated, in other words, their right to internal self-determination is not realized. Ch. Borgen explains this in the following way: "any attempt to claim a legal secession - that is, where secession trumps territorial integrity - must at least show that:

(1) the secessionists are a "people" (in the ethnographic sense);

(2) the state from which they are seceding seriously violates their human rights; and

(3) there are no other effective remedies under either domestic law or international law" (Borgen, 2008).

Among the constitutive elements of the people one may list language, customs, history and religion (objective elements), and motivation to preserve their identity (subjective element) (Dynia, 2007, p. 164), and - as evidenced above - all of them present in the case of indigenous peoples. 


\section{FORMS OF INDIGENOUS SELF-DETERMINATION}

UN Declaration on the Rights of Indigenous Peoples is the most important, however non-binding, instrument on the rights of indigenous peoples. It affirms that indigenous peoples "contribute to the diversity and richness of civilizations and cultures, which constitute the common heritage of humankind". According to the UN Declaration, indigenous peoples have a collection of rights: individual ones that persons have as members of the group and collective ones that inhere in the group as a whole (such as land rights) (Art. 1 of the UN Declaration). Art. 3 refers to the right of self-determination of indigenous peoples which means the ability freely to "determine their political status and freely pursue their economic, social and cultural development". Art. 4 expressly recognizes the right to autonomy or self-governance in the exercise of the right to self-determination. Self-determination is connected to the right to autonomy or self-governance in matters relating to internal and local affairs of indigenous peoples (Art. 4 of the UN Declaration. Cf. Kingsbury, 1992, pp. 501-503). This formula indicates that self-determination should be exercised first of all in the form of autonomy. To make things even clearer, the UN Declaration contains a clause stating that "Nothing in this Declaration may be interpreted as implying for any State, people, group or person any right to engage in any activity or to perform any act contrary to the Charter of the United Nations or construed as authorizing or encouraging any action which would dismember or impair, totally or in part, the territorial integrity or political unity of sovereign and independent States" (Art. 46). This formula seems to give priority to territorial integrity of a State over the right to secede. But still, many States fear that recognizing the right of indigenous peoples to self-determination may lead to secession. Those fears are, however, unjustified as most of indigenous peoples do not want to create a separate State but be able to make free and independent decisions in their own matters (Baer, 2005, p. 257; Okafor, 2002, pp. 41-70; Gunn, 2007, p. 58). The advisory opinion of the African Commission on Human and Peoples' Rights of 2007 on the UN Declaration on the Rights of Indigenous Peoples indicates that indigenous peoples have the right to self-determination, but this does not imply the right to unilateral secession (2007). Here I would like to quote from the President of the Ainu (indigenous peoples of Japan) Association Giichi Nomura who stated that: "[ $t]$ he right to selfdetermination was not a threat to the national unity or the territorial integrity of Member States. What the Ainu sought was a high level of autonomy based on the fundamental values of «co-existence with nature» and «peace through 
negotiation». They did not seek to create new States with which to confront those already in existence" (Barsh, 1994, p. 41). Kenneth Deer, Mohawk and former co-chair of the Indigenous Peoples' Caucus, adds - indicating important components of self-determination - that „[a]ll our rights either flow from or are linked to our right of self-determination. These include our right to land, our right to natural resources, our right to our language and culture, our right to our songs... 'Free, prior and informed consent' (FPIC) also flows from the right to self-determination" (Gunn, 2011, p. 10). Free, prior and informed consent may be regarded as "a form of legal empowerment of indigenous peoples" (Global Perspectives, 2013, p. 120).

Consequently, indigenous peoples have the right to "maintain and strengthen their distinct political, legal, economic, social and cultural institutions, while retaining their right to participate fully, if they so choose, in the political, economic, social and cultural life of the State" (Art. 5 of the UN Declaration). But as Erica-Irene Daes, the former Chairperson of the UN Working Group on Indigenous Populations, stated, "there is no distinction between indigenous and other peoples, save the indigenous people have not been able to exercise the right to self-determination" (Baer, 2005, p. 255; Gunn, 2011, p. 11). What is also important, the UN Declaration is not the source of the right to self-determination of indigenous peoples, it merely recognizes rights that inhere in indigenous peoples by way of their indigenous sovereignty dating back to long time before the emergence of States and conquest. Jérémie Gilbert and Valérie Couillard (2009, pp.30-31) point to the " pre-existing rights [that] could have had some beneficial consequences for indigenous peoples: if their rights pre-existed the colonial legal regime, they might also survive it". This is exactly the kind of argument underlying all the claims of indigenous peoples to their rights. Those pre-existing rights already and still belong to indigenous peoples (doctrine of continuation) but had been taken from them by conquest and it is high time to recognize and realize them (Gilbert \& Couillard, 2009, pp. 30-31). Nils Oskal (2001, p. 261) adds that the customary laws of indigenous peoples to use their lands and waters are based on long-term use, not just legal norms.

Moreover, the right to self-determination is of erga omnes character, hence the legal nature of the UN Declaration in this case is irrelevant (Case Concerning East Timor (Portugal v. Australia), 1995, para. 29; Wheatley, 2010, pp. 60-64; Abate \& Kronk, 2013, pp. 63-65). Moreover, despite its non-binding character, the UN Declaration "consolidates the rights of indigenous peoples already recognized in other human rights instruments and through the jurisprudence of international 
human rights treaty bodies" (Conservation and Indigenous Peoples' Rights, 2016, para. 22).

Still, from the analysis of the above mentioned provisions of the UN Declaration on self-determination and autonomy, it seems that despite Arts. 1 and 2 of the Declaration requiring from States ensuring equality and non-discrimination of indigenous peoples, preference for internal self-determination visible in the clause for Art. 46 contradicts this full equality with other peoples with reference to the right to self-determination. On the other hand, as mentioned above, even in the case of other peoples, international and national courts as well as scholars accept the right to external self-determination in the form of secession only exceptionally. However, external self-determination is not limited to secession. It may also encompass participation of indigenous peoples in international conferences and work of international bodies (Fitzmaurice, 2009, p. 144), for example, in the UN Permanent Forum on Indigenous Issues (https://www.un.org/development/desa/indigenouspeoples/unpfii-sessions-2.html), the Arctic Council where the Sami are taking part as permanent participants (Koivurova, 2008a, p. 286; Metcalf, 2003-2004, pp. 116-119; Poto, 2016, pp. 23-24) or very recently in the Paris climate talks in December 2015 during the Conference of the parties to the UN Framework Convention on Climate Change (http://www.iipfcc.org/). Many indigenous peoples have actively participated in the UN Open-Ended Working Group on the Declaration on the Rights of Indigenous Peoples and in the creation of the ILO Convention 169 as well as in the Organization of American States' Declaration on the Rights of Indigenous Peoples. As Brenda Gunn comments, "through their active participation in the drafting and negotiation process, various Indigenous peoples have been able to articulate their rights in a way that is meaningful to them" (Gunn, 2011, pp. 59-60; cf. Abate \& Kronk, 2013 , pp. 42-48). Another way to assert the right of self-determination in its external (or international) dimension was and still is to negotiate and conclude treaties (Gunn, 2011, p. 10).

One may claim that also Arts. 18-19 of the UN Declaration which refer to participation in decision-making provide additional arguments for claims to some form of autonomy. Art. 18 states that "Indigenous peoples have the right to participate in decision-making in matters which would affect their rights, through representatives chosen by themselves in accordance with their own procedures, as well as to maintain and develop their own indigenous decision making institutions". Art. 19 adds that "States shall consult and cooperate in good faith with the indigenous peoples concerned through their own representative 
institutions in order to obtain their free, prior and informed consent before adopting and implementing legislative or administrative measures that may affect them". The requirement of free, prior and informed consent should be emphasized as it is a mean that does not allow decisions to be made without the participation of the indigenous peoples concerned. However, generally it does not mean that indigenous peoples have a right to veto. "Participation should be seen as a "chief strategy through which to progress towards equity for indigenous peoples». It implies going further than mere consultation and should lead to the concrete ownership of projects on the part of indigenous peoples" (UN Resource Kit, 2008, p. 17). But as the Inter-American Court of Human Rights rightly indicated in the Saramaka People v. Suriname case, there is a clear distinction between situations in which full free, prior and informed consent is required and situations in which mere consultation can be sufficient. The Court introduced two tests that must be applied in order to determine these situations: first is the 'scale' of the project in question and the second is the 'impact' the project would have on indigenous lands. Development or investment projects which are 'large scale' and which would have a 'major' or 'significant impact' require not merely consultations but also the free, prior and informed consent of the indigenous communities affected which actually amounts to the veto right (paras. 136-137; Heinämäki et al., 20107, pp. 253-257; Anaya \& Williams, 2001, pp. 33-86).

ILO Convention 169 does not contain express rights to autonomy or any provisions on autonomy but states in Art. 6 that "In applying the provisions of this Convention, governments shall: (a) consult the peoples concerned, through appropriate procedures and in particular through their representative institutions, whenever consideration is being given to legislative or administrative measures which may affect them directly; (b) establish means by which these peoples can freely participate, to at least the same extent as other sectors of the population, at all levels of decision-making in elective institutions and administrative and other bodies responsible for policies and programmes which concern them; (c) establish means for the full development of these peoples' own institutions and initiatives, and in appropriate cases provide the resources necessary for this purpose. 2. The consultations carried out in application of this Convention shall be undertaken, in good faith and in a form appropriate to the circumstances, with the objective of achieving agreement or consent to the proposed measures". This provision clearly refers to the right to participate in governance which may be regarded as an aspect of self-governance. As can been seen, it does not mention the free, prior and informed consent. Also of relevance 
for self-determination are Arts. 2, 7, 8, 16 and 27 which refer to establishment of indigenous institutions and participation in activities that affect the indigenous interests, their culture, religion, identity, language and land rights. Right to autonomy is expressly mentioned in Art. XXI of the American Declaration on the Rights of Indigenous Peoples of 2016. Autonomy may be regarded as a method of exercising the right to self-determination (Allen, 2005, p. 197).

The right to autonomy as a form of internal self-determination of indigenous peoples may also be derived from the general human rights provisions, for example Art. 1 (the right of peoples to self-determination) and 27 (the right of persons belonging to ethnic, linguistic and religious minorities to enjoy their own culture) of the International Covenant on Civil and Political Rights (ICCPR). The Human Rights Committee interprets Art. 27 of the ICCPR as protecting the right of indigenous peoples to preservation of their livelihood, culture, language, traditional activities necessary for their survival and their customs (Ivan Kitok v. Sweden, 1988; Lubicon Lake Band v. Canada, 1990; Länsman et al. v. Finland, 1992; Apirana Mahuika et al. v. New Zealand, 2000). In General Comment no. 23 (1994, para. 7) the Committee stated that "With regard to the exercise of the cultural rights protected under article 27, the Committee observes that culture manifests itself in many forms, including a particular way of life associated with the use of land resources, especially in the case of indigenous peoples. That right may include such traditional activities as fishing or hunting and the right to live in reserves protected by law. The enjoyment of those rights may require positive legal measures of protection and measures to ensure the effective participation of members of minority communities in decisions which affect them".

Timo Koivurova (2008b, p. 6) claims that initially the Human Rights Committee regarded the indigenous peoples as protected by Art. 27 of the ICCPR but from 1999 (when the Committee adopted its Concluding Observations on the Periodic Report of Canada) also by Art. 1. There the Committee requested the government of Canada to report on the situation of indigenous peoples in the next periodic report not only under Art. 27, but also Art. 1 of the ICCPR. The Committee stated in its Concluding observations on Canada that " $t]$ he Committee, while taking note of the concept of self-determination as applied by Canada to the aboriginal peoples, regrets that no explanation was given by the delegation concerning the elements that make up that concept, and urges the State party to report adequately on implementation of article 1 of the Covenant in its next periodic report" (Concluding Observations of the Human Rights Committee on the Periodic Report of Canada, 1999, para. 7). This attitude was 
confirmed in the Apirana Mahuika et al v. New Zealand case (2000), albeit in a more cautious manner: "The Committee observes that the Optional Protocol provides a procedure under which individuals can claim that their individual rights have been violated. These rights are set out in part III of the Covenant, articles 6 to 27, inclusive. As shown by the Committee's jurisprudence, there is no objection to a group of individuals, who claim to be commonly affected, to submit a communication about alleged breaches of these rights. Furthermore, the provisions of article 1 may be relevant in the interpretation of other rights protected by the Covenant, in particular article 27" (Apirana Mahuika et al. v. New Zealand, 2000, para.9.2). Still Article 1 was regarded not as an autonomous basis of individual petition but as a factor relevant in the interpretation of Article 27. The Committee seems to be more courageous in its Concluding observations than when considering the individual petitions. Małgosia Fitzmaurice (2013, p. 354) notices that in the Apirana Mahuika et al. the Committee for the first time confirmed that Art. 1 of the ICCPR "may be relevant to the interpretation of other rights protected by the Covenant, in particular article 27". Subsequently the Committee referred to Art. 1 of the ICCPR in its Concluding observations, inter alia: on Denmark (2000) (para. 11), on Finland (2004) (para. 17), on Finland (2013) (para. 16), on Sweden (2002) (para. 15), on Sweden (2009) (paras. 20-21), and on Sweden (2016) (paras. 38-39). In the Concluding observations on Sweden of 2002 and 2009 (paragraphs 15 and 20, respectively) as well as on Finland of 2013 (paragraph 16), the Committee emphasised the need for the implementation of the rights of the Sami by strengthening the decision-making powers of the Sami representative institutions such as the Sami parliaments. This expressly translates into the self-governance and self-determination of the Sami.

Timo Koivurova sums up the work of the Human Rights Committee: "In sum, over the course of some 20 years, the HRC has gradually developed the rights enjoyed by indigenous peoples. In the first phase, indigenous rights were protected pursuant to the protection of minorities set out in Article 27; from 1999 onwards the Committee has regarded indigenous peoples as covered by Article 1 as well" (Koivurova, 2008b, p. 8), which offers stronger protection.

Based on the foregoing provisions listed above, many scholars claim that internal self-determination may be equated with local autonomy (Loukacheva, 2005 , p. 5). Natalia Loukacheva (2005, p. 5) regards the right to autonomy "as a realization of the principle of internal self-determination in the form of selfgovernance if several conditions exist". She then lists those conditions; they include: 
- Strong will of the population (in this case the indigenous peoples) to achieve autonomy;

- Cultural factor consisting of ethnic and cultural as well as linguistic differences;

- Geographical and historical conditions relevant to indigenous peoples;

- Condition related to democratic participation, namely the existence of a legislative organ elected by the local population (in this case indigenous peoples) and existence of executive body;

- Economic sustainability or some other financial base (Loukacheva, 2005, pp. 5-6).

As a result, as Natalia Loukacheva $(2005$, p. 7$)$ indicates, "the right to autonomy covers elements of effective participation in power-sharing and democratic institutions. It also extends to culture, including the ability of the minority group to maintain its culture, language, and religion and may extend to preserving the way of life of indigenous livelihood, including land rights and economic structures of indigenous peoples".

Concrete examples of implementing the right to self-determination as selfgovernance or a kind of autonomy are Sami parliaments in Sweden, Norway, and Finland. Accordingly, the draft Nordic Sami Convention mentions the right to self-determination in the preamble and Art. 3 and then it contains the whole Chapter II on the Sami governance (including regulations of the Sami parliaments and Sami organizations). Art. 3 stipulates: "As a people, the Saami has the right of self-determination in accordance with the rules and provisions of international law and of this Convention. In so far as it follows from these rules and provisions, the Saami people has the right to determine its own economic, social and cultural development and to dispose, to their own benefit, over its own natural resources" (https://www.regjeringen.no/globalassets/upload/aid/ temadokumenter/sami/sami_samekonv_engelsk.pdf; cf. Koivurova, 2008a, p. 288; Kymlicka, 2008, pp. 21-23; although in the end W. Kymlicka claims that there is no right to autonomy for national minorities, one must remember that the situation of indigenous peoples is different and conclusions regarding national minorities does not apply to indigenous peoples).

As Paul J. Magnarella indicates, "[a]utonomy does not jeopardize the territorial integrity of a State. It can be structured within constitutional framework of the State and can consist of a combination of political, economical and cultural elements. Autonomy can involve local control over some combination of education, religion, land use, taxation, family law, cultural institutions (e.g., 
museums, parks, etc.) and municipal government. It does not involve control over foreign policy, national defense, aviation, postal services, monetary policy, etc." (Magnarella, 2001-2002, p. 440). Autonomy may be based on contemporary indigenous political institutions, for example, the Sami Parliaments in the Nordic States. It may also be shaped as autonomy based on some territorial arrangements including the ancestral indigenous territories such as Comarca's Kuna Yala in Panama. Another form of autonomy involves regional autonomy within the State such as Nunavut territory in Canada (Magnarella, 2001-2002, p. 442; Loukacheva, 2005, pp. 17-18) or the Nisga'a territory in Canada (Report of the Special Rapporteur on the Situation of Human Rights and Fundamental Freedoms of Indigenous People, Rodolfo Stavenhagen, 2004, para. 27; Hoffman \& Robinson, 2010, pp. 387-405). Accordingly, autonomy does not have to take a territorial form, meaning that parts of the territory are authorized to self-governance but it may also involve the authorization of indigenous peoples to enact their own laws, to have their own courts and use their own lands according to their customs, traditions and present and future needs. Although in the interest and well-being of the indigenous peoples their traditional lands should be delimited.

Prosper N. Musafiri points to three forms of autonomy: territorial autonomy, personal autonomy and functional autonomy. The first one envisages some form of "regional executive institutions and elected representations of the people(s) for the purpose of linking the political activities within the regional unit with the will of its inhabitants. Powers transferred to an autonomous region may range from a decentralisation in administrative matters over far-reaching self-government with certain legislative powers, to a virtually independent administrative, legislative and judicial system" (Musafiri, 2012, p. 523). The example of it is the autonomy of Greenland recognized by Denmark.

Personal autonomy "is granted collectively to all members of a minority irrespective of whether they belong to a certain territorial administrative unit. This may include an own representative legislative body, and an executive competent for areas such as culture, language and education" (Musafiri, 2012, p. 524). The most known such institutions are the Sami parliaments in the Nordic States: Sweden, Norway, and Finland. All those bodies started with only advisory role but with time they acquired more meaningful competences such as deciding on their own priorities within the budget of the State (Norway) or full cultural autonomy (as in Finland) (Musafiri, 2012, p. 524).

Finally, functional autonomy "pertains to the devolution of certain powers with a view to culture, education, religious issues or media to indigenous [...] 
organisations constituted as juristic persons of private law. In contrast to personal autonomy, not all members of the indigenous people [...] are subjected to empowered body, but only those who are members of the respective indigenous [...] organisation" (Musafiri, 2012, p. 526).

Nuuk Conclusions and Recommendations on Indigenous Autonomy and SelfGovernment of 1991 argue that autonomy is essential for indigenous peoples, primarily because it is a fundamental condition of equality and dignity, freedom from discrimination and full respect for the human rights of indigenous peoples (Art. 4). Autonomy also provides benefits in the field of environmental protection and maintaining the ecological balance necessary to ensure sustainable development (Art. 6) (Loukacheva, 2005, p. 14). Autonomy, as a form of selfdetermination, in its internal dimension, and self-government enable indigenous peoples to participate in public life and in decision-making in matters that affect them. Implementation of the right to self-determination is crucial to the survival of indigenous peoples and their social, political, economic and cultural development (Loukacheva, 2005, p. 14), in other words, their human security. As Kamrul Hossain (2012, p. 496) affirms, strengthening the idea of self-determination will provide the indigenous peoples with greater authority in the field of human security, hence they will be capable to provide this security on their own.

As mentioned above, realizing self-determination in the form of selfgovernance and participation include creating indigenous associations, political parties or participation in them, indigenous parliaments and other bodies, local self-governance in the form of territorial autonomy (as in Greenland). Self-determination is closely linked to the development and central to the latter are land rights and access and control of indigenous peoples over them (UN Resource Kit, 2008, p. 13). As pointed out in the publication on indigenous peoples prepared under the auspices of the UN, one of the deep reasons for the marginalization of indigenous peoples is the loss of control over their lands, territories and natural resources. The refusal to respect their rights to sustainable management of lands and natural resources has contributed to the further marginalization and exclusion of indigenous peoples (UN Resource Kit, 2008, p. 10).

Land rights strengthen the right to self-determination, not only in the form of territorial autonomy (Allen, 2005, p. 208). Arts. 25-26 and 28 of the UN Declaration recognize the special meaning of the lands of indigenous peoples and their spiritual relation with the land (Graver \& Ulfstein, 2004, pp. 337-377; Minde, 2001, pp. 107-125). The rules related to lands and natural resources include the recognition of the indigenous peoples' rights to their lands and territories, 
the latter being demarcated and protected. Indigenous peoples must be able to determine the activities that take place on their lands, especially taking into account the impact of such activities on the environment and sacred and cultural sites of indigenous peoples. International community as a whole and particular States must also recognize the rights of indigenous peoples to resources that are essential to their subsistence and development. Finally, even if States are the owners of the sub-surface resources in indigenous lands, indigenous peoples' free, prior and informed consent should still be required for the exploration and exploitation of those resources and indigenous peoples should benefit from any such activities (UN Resource Kit, 2008, p. 16). As Erica-Irene Daes indicates: "Land is not only an economic resource for Indigenous Peoples. It is also the peoples' library, laboratory and university; land is the repository of all history and scientific knowledge. All that Indigenous Peoples have been, and all that they know about living well and humanely is embedded in their land and in the stories associated with every feature of the land and landscape" (Daes, 2001, pp. 264-265). Lands are a source of the indigenous peoples' survival, well being and spiritual perseverance.

There is also a group of documents prepared and adopted by representatives of the indigenous peoples in which they demand the implementation of their right to self-determination. For example, in the Earth Charter adopted at the 1992 Kari-Oca conference, indigenous peoples insist on respect for their right to selfdetermination (paragraph 14) and their traditional way of life (paragraph 16). Indigenous peoples also demand respect for their right to development according to their cultural practices and economic and ecological vitality (paragraph 62). In very strong words, the Earth Charter states that Western concepts of development meant the destruction of the lands of indigenous peoples. Therefore, these peoples reject the current definition of economic development (paragraph 66). Also in the 1996 Seattle Declaration, indigenous peoples have called for alternative models of development, demanding recognition and respect for their rights to lands and natural resources, and to continue their practices in the field of sustainable agriculture and management of natural resources. 


\section{CONCLUDING REMARKS}

In 2007, the UN Declaration on the Rights of Indigenous Peoples was adopted. UN Declaration is the most important, however non-binding, instrument on the rights of indigenous peoples. Art. 3 of the Declaration refers to the right of self-determination of indigenous peoples which means the ability freely to "determine their political status and freely pursue their economic, social and cultural development". Self-determination is connected to the right to autonomy or self-governance in matters relating to internal and local affairs of indigenous peoples. Many States fear that according the indigenous peoples the right to selfdetermination may lead to secession. Those fears are however unjustified as most indigenous peoples do not want to create a separate State but be able to make free and independent decisions in their own matters. Consequently, indigenous peoples have the right to "maintain and strengthen their distinct political, legal, economic, social and cultural institutions, while retaining their right to participate fully, if they so choose, in the political, economic, social and cultural life of the State" (Art. 5 of the UN Declaration). In the new millennium more and more indigenous peoples want some form of self-governance as a form of internal self-determination. Such arrangements give them a sense of control over their own destiny, their livelihoods and well-being as well as their ability to preserve and develop their culture, language, customs and traditions (Loukacheva, 2005, p. 11). One must remember that indigenous peoples were the owners of their land before they came in contact with the colonizers. Indigenous peoples are the first peoples. Their right to self-determination must not be denied them.

Still, Timo Koivurova is of the opinion that all the numerous drafts, treaties and declarations "have raised excessive expectations among the indigenous peoples; after all, the drafts must be accepted by the representatives of states. The same applies to the normative activities of the UN treaty monitoring bodies [...] whose mandate is to interpret their respective treaties and whose interpretation become authoritative only if states do not oppose them" (Koivurova, 2008b, p. 2 ). This clearly pertains to the right to self-determination. Surely the right to self-determination was not supposed to embrace the external aspect (the right to secession). R.L. Barsh (1994, p. 36) indicates to an approach challenging the widespread assumption that self-determination always entails secession. He claims that indigenous peoples' self-determination may be realized in the form of autonomy which may involve restructuring of existing States so that the rights, interests and development of indigenous peoples may be preserved and protected. 
To summarize, generally indigenous peoples are entitled to self-determination in the form of autonomy and only as a last resort to remedial secession, although so far this has not occurred in practice. The right to a remedial secession depends on "the degree to which the government of the State in question represents its indigenous peoples. If the government is quite unrepresentative and oppressive, the international community may recognize secession and independence as a legitimate claim" (Magnarella, 2001-2002, p. 447). However, indigenous peoples may also exercise some elements of the right to external self-determination, for example in the form of representation in inter-state affairs and in international relations in general (Koivurova, 2008b, p. 15). Some forms of the external participation may take the form of participation of indigenous peoples in international conferences and UN organs such as Permanent Forum on Indigenous Issues. One should also remember that " $\mathrm{t}]$ he whole point of self-determination is not to preserve cultural isolation, or a static way of life, but rather to ensure fair terms of interaction, and to enable indigenous peoples to decide for themselves when and how to borrow from other cultures" (Musafiri, 2012, pp. 505-506). This was expressly stated in the jurisprudence of the Human Rights Committee. For example, in the case of Länsman et al. v. Finland (1992, para. 9.3) it was stated that: "The right to enjoy one's culture cannot be determined in abstracto but has to be placed in context. In this connection, the Committee observes that article 27 does not only protect traditional means of livelihood of national minorities, as indicated in the State party's submission. Therefore, that the authors may have adapted their methods of reindeer herding over the years and practice it with the help of modern technology does not prevent them from invoking article 27 of the Covenant".

Referring to the main research question posed in the introduction on whether indigenous peoples have the right to the same self-determination as other peoples, the answer is a bit complex. The above analysis reveals an important gap between the law in books (theory) and the law in action (practice or implementation). With reference to the theoretical dimension one may claim that all the international universal and regional instruments recognize the right of indigenous peoples to self-determination in the same way as for other peoples but the problem is with its practical implementation. Self-determination may be realized in different forms, according to indigenous peoples' own needs and aspirations (Gunn, 2011, p. 11). The international instruments on the rights of indigenous peoples devote much attention to the issue of autonomy. Self-governance and autonomy are unfortunately rather the exception than the rule. Indigenous 
peoples still have to face problems with their recognition as such by States. As shown, many Asian and African States do not even recognize indigenous peoples. In the decolonization era indigenous peoples did not benefit from it and were not entitled to establish their own States or some form of autonomy. In that period, the doctrine of terra nullius found its continuance in the doctrine of $u t i$ possidetis, according to which the newly formed States "inherited" the colonial boundaries, meaning that they emerged within the boundaries of the former colonies. This can be considered as a continuation of the colonial heritage, as indigenous peoples were not recognized as carriers of sovereignty and statehood. Indigenous lands became parts of modern States while simultaneously States refused them the right to the lands they occupied before the emergence of those States. Current international law's role is to overcome the negative effects of colonization and provide the indigenous peoples with fair redress (Kuppe, 2009, p. 108).

Indigenous self-determination usually takes a more informal form - that of autonomy or other form of self-governance, expressed, for example, by the Sami parliaments in the Nordic States or the Greenland self-governance in Denmark. Organs representing indigenous peoples enjoy more or less power but they are always subordinate to the State organs. This is problematic as the idea of selfgovernance and development currently implemented to a huge extent reflects the Western or Eurocentric ways of thinking (Christie, 2007, pp. 13-29). In order to improve the situation it is indispensable to fully recognise the indigenous sovereignty and the pre-existing rights of indigenous peoples, especially to their lands and natural resources that are necessary for their survival and maintenance of their identity and culture.

\section{REFERENCES:}

Abate, R., \& Kronk, E.A. (eds.) (2013). Climate Change and Indigenous Peoples: The Search for Legal Remedies. Cheltenham: Edward Elgar Publishing.

Advisory Opinion of the African Commission of Human and Peoples' Rights on the United Nations Declaration on the Rights of Indigenous Peoples (2007). Retrieved from: http://www.achpr.org/files/special-mechanisms/indigenous-populations/ un_advisory_opinion_idp_eng.pdf.

Allen, S. (2005). Establishing Autonomous Regimes in the Republic of China: The Salience of International Law for Taiwan's Indigenous Peoples. Indigenous Law Journal, $4(1), 159-217$. 
American Declaration on the Rights of Indigenous Peoples (2016). Retrieved from: http://www.iitc.org/program-areas/treaties-standard-setting/the-oas-americandeclaration-on-the-rights-of-indigenous-peoples/.

Anaya, J.S. (1996). Indigenous Peoples in International Law. Oxford: Oxford University Press.

Anaya, J.S., \& Williams Jr., R.A. (2001). The Protection of Indigenous Peoples' Rights over Lands and Natural Resources Under the Inter-American Human Rights System. Harvard Human Rights Journal, 14, 33-86.

Antonowicz, L. (2011). Podręcznik prawa międzynarodowego. Warszawa: Wydawnictwo Prawnicze LexisNexis.

Antonowicz, L. (2012). Rzecz o państwach i prawie międzynarodowym. Lublin: Innovatio Press Wydawnictwo Naukowe Wyższej Szkoły Ekonomii i Innowacji w Lublinie.

Apirana Mahuika et al. v. New Zealand (2000). Retrieved from: http://juris.ohchr.org/ Baer, L.A. (2005). The Rights of Indigenous Peoples - A Brief Introduction in the Context of the Sámi. International Journal on Minority and Group Rights, 12(2-3), 245-267.

Barcik, J., \& Srogosz, T. (2007). Prawo międzynarodowe publiczne. Warszawa: C.H. Beck. Barsh, R.L. (1994). Indigenous Peoples in the 1990s: From Object to Subject of International Law? Harvard Human Rights Journal, 7, 33-86.

Białocerkiewicz, J. (2007). Prawo międzynarodowe publiczne. Zarys wykładu. Toruń: TNOiK.

Borgen, Ch. (2008). Kosovo's Declaration: Analyzing the Legal Issues of Secession and Recognition. Retrieved from: http://opiniojuris.org/2008/02/20/kosovosdeclaration-analyzing-the-legal-issues-of-secession-and-recognition/.

Cassese, A. (2005). International Law. Oxford: Oxford University Press.

Christie, G. (2007). Culture, Self-Determination and Colonialism: Issues Around the Revitalization of Indigenous Legal Traditions. Indigenous Law Journal, 6(1), 13-29.

Concluding Observations of the Human Rights Committee on the Periodic Report of Canada (1999). Retrieved from: http://tbinternet.ohchr.org/_layouts/treatybodyexternal/TBSearch.aspx?Lang=en \& TreatyID $=8 \&$ Doc TypeID $=5$.

Conservation and Indigenous Peoples' Rights. Report to the General Assembly, 29 July 2016. Retrieved from: http://unsr.vtaulicorpuz.org/site/index.php/documents/ annual-reports/149-report-ga-2016.

Crawford, J. (1979). The Creation of States in International Law. Oxford: Clarendon Press.

Crawford, J. (2007). The Creation of States in International Law (2 ${ }^{\text {nd }}$ ed.). Retrieved from: http://opil.ouplaw.com/view/10.1093/law/9780199228423.001.0001/law9780199228423-chapter-9.

Czapliński, W., \& Wyrozumska, A. (2004). Prawo międzynarodowe publiczne. Zagadnienia systemowe. Warszawa: C.H. Beck.

Daes, E.I. (2001). The Concepts of Self-Determination and Autonomy of Indigenous Peoples in the Draft United Nations Declaration on the Rights of Indigenous Peoples. St. Thomas Law Review, 14, 259-269. 
Declaration on Principles of International Law Concerning Friendly Relations and Co-operation Among States in Accordance with the Charter of the United Nations (1970). Retrieved from: http://www.un-documents.net/a25r2625.htm.

Declaration on the Granting of Independence to Colonial Countries and Peoples (1960). Retrieved from: http://www.un.org/en/decolonization/declaration.shtml.

Dynia, E. (2007). Problem samostanowienia i ochrony praw ludów tubylczych we współczesnych stosunkach międzynarodowych. In: A. Bartkiewicz (ed.), Ludy tubylcze. Czwarty Świat, dziedzictwo kolonializmu, skanseny świata czy partnerzy narodów? (pp. 155-171). Warszawa: Comandor.

Fitzmaurice, M. (2009). The New Developments Regarding the Saami Peoples of the North, International Journal on Minority and Group Rights, 16(1), 67-156. DOI: 10.1163/157181109X394380.

Fitzmaurice, M. (2013). The Question of Indigenous Peoples' Rights: A Time for Reappraisal? In: D. French (ed.), Statehood and Self-Determination: Reconciling Traditions and Modernity in International Law (pp. 349-376). Cambridge: Cambridge University Press.

General Comment No. 23 of 1994. Retrieved from: http://tbinternet.ohchr.org/_layouts/ treatybodyexternal/TBSearch.aspx?Lang=en $\&$ TreatyID $=8 \&$ DocTypeID $=11$.

Gilbert, J., \& Couillard, V. (2009). Land Rights Under International Law: Historical and Contemporary Issues. In: Land Rights and the Forest Peoples of Africa. Historical, Legal and Anthropological Perspectives (pp. 28-47). Retrieved from: http://roar.uel. ac.uk/2646/1/overviewlandrightsstudy09eng.pdf.

Global Perspectives (2013). In: R.S. Abate, \& E.A. Kronk (eds.), Climate Change and Indigenous Peoples: The Search for Legal Remedies (pp. 119-120). Cheltenham: Edward Elgar Publishing.

Graver, H.P., \& Ulfstein, G. (2004). The Sami People's Right to Land in Norway. International Journal on Minority and Group Rights, 11(4), 337-377.

Gunn, B. (2007). Protecting Indigenous Peoples' Lands: Making Room for the Application of Indigenous Peoples' Laws Within the Canadian Legal System. Indigenous Law Journal, 6(1), 31-69.

Gunn, B. (2011). Understanding and Implementing the UN Declaration on the Rights of Indigenous Peoples: An Introductory Handbook. Retrieved from: http://quakerservice.ca/wp-content/uploads/2011/10/UNDRIP_Handbook_IBA.pdf.

Heinämäki L. et al. (2017). Actualizing Sámi Rights: International Comparative Research, Publications of the Government's analysis, assessment and research activities. Retrieved from: http://tietokayttoon.fi/julkaisu?pubid $=16601$.

Hoffman, R., \& Robinson, A. (2010). Nisga'a Self-Government: A New Journey Has Begun. Canadian Journal of Native Studies, 30(2), 387-405.

Hossain, K. (2012). Securing the Rights: A Human Security Perspective in the Context of Arctic Indigenous Peoples. The Yearbook of Polar Law, 5(1), 493-522.

ILO Convention 107 on the Protection and Integration of Indigenous and Other Tribal and Semi-Tribal Populations in Independent Countries (1957). Retrieved from: 
http://www.ilo.org/dyn/normlex/en/f?p=NORMLEXPUB:12100:0::NO::P121 00_INSTRUMENT_ID:312252.

ILO Convention 169 on Indigenous and Tribal Peoples in Independent Countries (1989). Retrieved from: http://www.ilo.org/dyn/normlex/en/f?p=NORMLEXPU B:12100:0::NO::P12100_ILO_CODE:C169.

Indigenous Peoples and ASEAN Integration (2015). Asia Indigenous Peoples Pact. Retrieved from: http://aippnet.org/indigenous-peoples-and-asean-integration/.

Indigenous Peoples' Seattle Declaration on the Occasion of the Third Ministerial Meeting of the World Trade Organization (1999). Retrieved from: http://www.ienearth. org/indigenous-peoples-seattle-declaration/.

Inter-American Court of Human Rights, Case of the Saramaka People v. Suriname, Judgment of November 28, 2007 (Preliminary Objections, Merits, Reparations, and Costs).

International Court of Justice, Case Concerning East Timor (Portugal v. Australia), Judgment of 30 June 1995. Retrieved from: http://www.icj-cij.org/en/case/84.

International Covenant on Civil and Political Rights (1966). Retrieved from: http:// www.ohchr.org/en/professionalinterest/pages/ccpr.aspx.

International Indigenous Peoples' Forum on Climate Change. Retrieved from: http:// www.iipfcc.org/.

Ivan Kitok v. Sweden (1988). Retrieved from: http://juris.ohchr.org/.

Kałduński, M. (2010). Samostanowienie (Zasada samostanowienia narodów). In: M. Balcerzak, \& S. Sykuna (eds.), Leksykon ochrony praw człowieka. 100 podstawowych pojęć (pp. 441-450). Warszawa: C.H. Beck.

Kari-Oca Declaration and the Indigenous Peoples' Earth Charter, World Conference of Indigenous Peoples on Territory, Environment and Development, Kari-Oca 25-30 May 1992. Retrieved from: http://www.lacult.unesco.org/lacult_en/docc/ Kari-Oca_1992.doc.

Kingsbury, B. (1992). Claims by Non-State Groups in International Law. Cornell International Law Journal, 25(3), 481-513.

Kingsbury, B. (2008). "Indigenous Peoples" in International Law: A Constructivist Approach to the Asian Controversy. In: Ch. Erni (ed.), The Concept of Indigenous Peoples in Asia: A Resource Book (pp. 103-157). Copenhagen: Transaction Publishers.

Koivurova, T. (2008a). The Draft Nordic Saami Convention: Nations Working Together, International Community Law Review, 10(3), 279-293.

Koivurova, T. (2008b). From High Hopes to Disillusionment: Indigenous Peoples' Struggle to (Re)Gain Their Right to Self-Determination. International Journal on Minority and Group Rights, 15(1), 1-26.

Kownacki, R. (2010). Prawo Kosowa do samostanowienia: w oczekiwaniu na opinię doradczą MTS. Polski Przegląd Dyplomatyczny, 1, 100-110.

Kuppe, R. (2009). The Three Dimensions of the Rights of Indigenous Peoples. International Community Law Review, 11(1), 103-118. DOI: 10.1163/187197309X401424. 
Kymlicka, W. (2008). The Internationalization of Minority Rights. International Journal of Constitutional Law, 6(1), 1-32.

Loukacheva, N. (2005). On Autonomy and Law. Retrieved from: https://www.socialsciences.mcmaster.ca/institute-on-globalization-and-the-human-condition/documents/IGHC-WPS_05-3_Loukacheva.pdf.

Lubicon Lake Band v. Canada (1990). Retrieved from: http://juris.ohchr.org/.

Länsman et al. v. Finland (1992). Retrieved from: http://juris.ohchr.org/.

MacKay, F. (2005). The Draft World Bank Operational Policy 4.10 on Indigenous Peoples: Progress or More of the Same? Arizona Journal of International and Comparative Law, 22, 65-98.

Magnarella, P.J. (2001-2002). The Evolving Right of Self-Determination of Indigenous Peoples. St. Thomas Law Review, 14(2), 425-447.

Martínez Cobo, J. (1986/87). Study of the Problem of Discrimination Against Indigenous Populations. UN Doc E/CN.4/Sub.2/1986/7. New York: UN.

Marxsen, Ch. (2014). Crimea's Declaration of Independence. Retrieved from: http://www. ejiltalk.org/crimeas-declaration-of-independence/.

Meijknecht, A. (2002-2003). The (Re-)Emergence of Indigenous Peoples as Actors in International Law. Tilburg Law Review, 10(4), 315-324. DOI: 10.1163/ 221125 903X00023.

Metcalf, Ch. (2003-2004). Indigenous Rights and the Environment: Evolving International Law. Ottawa Law Review, 35(1), 101-140.

Minde, H. (2001). Sami Land Rights in Norway: A Test Case for Indigenous Peoples. International Journal on Minority and Group Rights, 8(2-3), 107-125.

Musafiri, P.N. (2012). Right to Self-Determination in International Law: Towards Theorisation of the Concept of Indigenous Peoples/National Minority. International Journal on Minority and Group Rights, 19(4), 481-532.

Nordic Saami Convention [in English]. Retrieved from: https://www.regjeringen.no/ globalassets/upload/aid/temadokumenter/sami/sami_samekonv_engelsk.pdf.

Oguamanam, Ch. (2004). Indigenous Peoples and International Law: The Making of a Regime. Queen's Law Journal, 30(1), 348-399.

Okafor, O.Ch. (2002). Entitlement, Process, and Legitimacy in the Emergent International Law of Secession. International Journal on Minority and Group Rights, 9(1), 41-70.

Operational Policy 4.10 - Indigenous Peoples (2005). World Bank. Retrieved from: https://policies.worldbank.org/sites/ppf3/PPFDocuments/090224b0822f89d5.pdf.

Oskal, N. (2001). Political Inclusion of the Saami as Indigenous People in Norway. International Journal on Minority and Group Rights, 8(2-3), 235-261.

Permanent Forum on Indigenous Issues. Retrieved from: https://www.un.org/development/desa/indigenouspeoples/unpfii-sessions-2.html.

Policy on Indigenous Peoples (1998). Asian Development Bank. Retrieved from: https:// www.adb.org/documents/policy-indigenous-peoples. 
Poto, M. (2016). The Arctic Council as an Actor in the Global Governance. In: T. Koivurova, \& W. Hasanat (eds.), Current Developments in Arctic Law, Vol. 4 (pp. 21-24). Rovaniemi: University of Lapland.

Reference Re Secession of Quebec Case (1998). Retrieved from: http://opil.ouplaw.com/ view/10.1093/law:ildc/184ca98.case.1/law-ildc-184ca98?rskey=3vj7g0\&result=5 \&prd=ORIL.

Report of the African Commission's Working Group of Experts on Indigenous Populations/Communities. Submitted in Accordance with the "Resolution on the Rights of Indigenous Populations/Communities in Africa” Adopted by the African Commission on Human and Peoples' Rights at Its $28^{\text {th }}$ Ordinary Session (2005). Retrieved from: http://www.iwgia.org/iwgia_files_publications_files/African_Commission_book.pdf.

Report of the Special Rapporteur on the Situation of Human Rights and Fundamental Freedoms of Indigenous People, Rodolfo Stavenhagen. Addendum. Mission to Canada. 2 December 2004. Retrieved from: http://www.gcc.ca/pdf/INT000000012. pdf.

Report of the Special Rapporteur on the Rights of Indigenous Peoples, James Anaya. Addendum. Consultation on the Situation of Indigenous Peoples in Asia. A/ HRC/24/41/Add.3, 31 July 2013. Retrieved from: http://unsr.jamesanaya.org/ special-reports/consultation-on-the-situation-of-indigenous-peoples-in-asia.

Schreiber, H. (2009). Ludy tubylcze jako nowy aktor we współczesnych stosunkach międzynarodowych. In: G. Piwnicki, \& S. Mrozowska (eds.), Jednostkaspołeczeństwo-państwo wobec megatrendów współczesnego świata (pp. 297-308). Gdańsk: Wydawnictwo Uniwersytetu Gdańskiego.

Separate Opinion of Judge Cançado Trindade to the ICJ Advisory Opinion on the Accordance with International Law of the Unilateral Declaration of Independence in Respect of Kosovo. Retrieved from: http://www.icj-cij.org/docket/index.php?p1 $=3 \& \mathrm{p} 2=4 \& \mathrm{k}=21 \& \operatorname{case}=141 \& \operatorname{code}=\mathrm{kos} \& \mathrm{p} 3=4$.

Symonides, J. (2007). Prawa ludów tubylczych w regulacjach międzynarodowych. In: A. Bartkiewicz (ed.), Ludy tubylcze. Czwarty Świat, dziedzictwo kolonializmu, skanseny świata czy partnerzy narodów? (pp. 235-254). Warszawa: Wydawnictwo Comandor. Tyranowski, J. (1997). Suwerenna równość, samostanowienie i interwencja. In: C. Mik (ed.), Pokój i sprawiedliwość przez prawo międzynarodowe. Zbiór studiów z okazji sześćdziesiatej rocznicy urodzin Profesora Janusza Gilasa (pp. 399-410). Toruń: TNOiK.

UN Charter (1945). Retrieved from: http://www.un.org/en/charter-united-nations/.

UN Declaration on the Rights of Indigenous Peoples, 2007, (UN GA res. 61/295). Retrieved from: http://research.un.org/en/docs/ga/quick/regular/61.

UN GA res. 48/163 of 21 December 1993. Retrieved from: http://research.un.org/en/ docs/ga/quick/regular/48.

UN GA res. 59/174 of 20 December 2004. Retrieved from: http://research.un.org/en/ docs/ga/quick/regular/59. 
UN Resource Kit on Indigenous Peoples' Issues. Department of Social and Economic Affairs, New York (2008). Retrieved from: http://www.un.org/esa/socdev/unpfii/ documents/resource_kit_indigenous_2008.pdf.

Vidmar, J. (2014). Crimea's Referendum and Secession: Why it Resembles Northern Cyprus More than Kosovo. Retrieved from: http://www.ejiltalk.org/crimeas-referendumand-secession-why-it-resembles-northern-cyprus-more-than-kosovo/.

Wheatley, S. (2010). The Legal Status of the UN Declaration on the Rights of Indigenous Peoples. Inter Alia - Student Law Review, 60, 60-64.

Working Paper on the Concept of Indigenous People (1996). Retrieved from: https:// pl.scribd.com/document/16533021/Evolution-of-Standards-Concerning-RightsOg-Indigenous-People. 